\title{
Greek Nursery School Teachers' Thoughts and Self-Efficacy on using ICT in Relation to Their School Unit Position: The Case of Kavala
}

\author{
Stefanos Goumas, Symeon Symeonidis, and Michail Salonidis \\ Business Administration Department, Technological Educational \\ Institute of Eastern Macedonian and Trace, Kavala, Greece
}

\author{
goumas@teiemt.gr, simsymeon@yahoo.gr, mdsa86a@gmail.com
}

\begin{abstract}
The purpose of this research is the exploration of the opinions and level of self-efficacy in the usage of Information Communication Technologies (ICTs) of teachers in Greek pre-schools in the learning process and administration of nurseries. By using the term "usage and utilisation of ICTs in the learning process" we mean the utilisation of the capabilities that new technologies offer in an educationally appropriate way so that the learning process yields positive results. By using the term "self-efficacy" we describe the strength of one's belief in one's own ability to use the capabilities he or she possess. In this way, the beliefs of the person in his or her ability to use a personal computer constitute the self-efficacy in computer usage. The research sample consists of 128 pre-school teachers that work in the prefecture of Kavala. Kavala's prefecture is a representative example of an Education Authority since it consists of urban, suburban, and rural areas. The approach that is deemed to be the most appropriate for the exploration of such research questions is content analysis methodology and correlation analysis. The main findings of the study have shown statistically significant differences regarding the opinions and stances of the preschool teachers for the introduction of the ICTs in the administration and the usage and utilisation of ICTs in the administration and preparation of teaching. Lastly, there were statistically significant differences between the opinions and stances of the pre-school teachers for the usage and utilisation of ICTs in the learning process. Instead, there were no statistically significant differences regarding the level of self-efficacy of the pre-school teachers in the usage and utilisation of the ICTs in the learning process. The research results could be used in the educational field as well as by Greek Ministry of Education, Research and Religious Affairs in order to take any corrective action, after the effort of Greek Ministry of Education, Research and Religious Affairs, to integrate ICT in the learning process with training courses since 2006.
\end{abstract}

Material published as part of this publication, either on-line or in print, is copyrighted by the Informing Science Institute. Permission to make digital or paper copy of part or all of these works for personal or classroom use is granted without fee provided that the copies are not made or distributed for profit or commercial advantage AND that copies 1) bear this notice in full and 2) give the full citation on the first page. It is permissible to abstract these works so long as credit is given. To copy in all other cases or to republish or to post on a server or to redistribute to lists requires specific permission and payment of a fee. Contact Publisher@InformingScience.org to request redistribution permission.
Keywords: ICT, educational process, use \& development of ICT, self-efficacy

\section{Introduction}

In the last decade, a very broad debate has been launched on the integration of new technologies in the educational process and how it benefits students and also teachers both in cognitive and educational level (Jimoyiannis, 2008). Although teachers acknowledge the im- 
portance of the usage of Information Communication Technologies (ICTs) in teaching practice, they seem reluctant to apply them in their daily teaching practice; when using them they apply them as teaching assistance means (for example, collection of information from the internet, worksheets in word, PowerPoint presentations) and not as a meaningful learning tool (Jimoyiannis, 2008).

One of the factors that hinder the integration of ICTs in the educational process is the inability of teachers to utilise them pedagogically. It seems that the training that enhances their knowledge about the handling of these instruments and cultivates the technical skills of the learners is not enough for their use as learning tools (Jimoyiannis \& Komis, 2006; Sim \& Theng, 2007).

One would therefore expect that after training on the didactic use of ICTs according to one's specialty, things would change radically. But such a change did not happen. Surveys in various educational disciplines have shown that even after the completion of the B-Level Informatics training of teachers program, they continue to use new technologies as a tool or with the traditional teacher-centered way (Passa, 2010, Trapsioti, 2010). Also, studies have shown that, although the programs that were carried out have had positive results on the use and utilisation of ICTs in the learning teaching process, they remained in the presentation rather than the practical side. This is something that both trainers and the trainees agree with (Mainas, 2009; Zetta, Papaconstantinou, \& Apostolidis, 2009).

\section{Theoretical Framework - Clarification of Conditions}

The current study makes use of the terms "usage and utilisation of ICTs in the learning process" and "self-efficacy." By using the term "usage and utilisation of ICTs in the learning process" we mean the exploitation of the capabilities that new technologies offer in an educationally appropriate way so that the educational and learning process yields positive results (EAITY, 2009). By using the term "self-efficacy" we describe the strength of one's belief in one's own ability to use the capabilities one possess (Bandura, 1997, referring to Kassotakis \& Roussos, 2006). In this way, the beliefs of the person in his or her ability to use a personal computer constitute selfefficacy in computer usage (Kassotakis \& Roussos, 2006). According to international researchers, self-efficacy plays an important role in the development of computer abilities and in one's decision to use them (Compeau \& Higgins, 1995). The degree of self-efficacy in an individual's computer use can be measured with appropriate scales.

\section{Literature Review}

There exist quite a few studies regarding the pre-school usage and utilisation of ICTs. Lovari and Charalambous (2006) realised that the usage of ICTs in the process of teaching and learning can increase the knowledge and the interest of pre-school aged kids in learning in comparison to conventional means of teaching. In addition, through the results of this research it is obvious that teaching ICT skills can start from the pre-school age when this happens through games and creative activities. Furthermore, Gialamas, Zaranis, and Tsara (2009) have shown that in general Greek female pre-school teachers form a positive opinion regarding the usage of technology as a means of teaching and learning of mathematical concepts by kids in the pre-school age.

Goti and Ntinas (2010) attempted to record the change of opinion of teachers for the usage of PCs in nurseries throughout a period of time. Studying the findings it can be seen that for a period of twelve years (1998-2010) the presence of PCs in the direct environment of the pre-school teachers is not restrained anymore and that its usage is wider. The vast majority of the nursery teachers agree with the inclusion of PCs in the preschool classes. The integration will positively affect the development of the mental and the creative imagination field, the development and cultivation of oral and written skills as well as mathematical thinking. By using the PCs in the classroom the 
individual pace of the child is respected. The authors' realization that the nursery that took part in the study encounter the PCs positively and wishes to use them is probably related to the training they received during the last years. The results of the study of Christodoulou-Gliaou and Gourgiotou (2009) have shown the positive stances of all nursery school teachers in the utilisation of the PCs in the learning process in the nursery school under the following conditions: the teachers should be continuously trained; they should have the appropriate logistical infrastructure and also the appropriate educational software. Petrogiannis (2010) found that after the new curriculum of the Greek Ministry of Education, Research and Religious Affairs was introduced there is still an important proportion of nursery teachers that do not have any experience of PC usage either in general or for educational purposes. Furthermore, it was found that the level of the knowledge of PCs that the nursery school teachers have has a positive effect on their stance towards technology and the perspective of integrating ICTs in the pre-school classes. On the other hand, Oikonomidis and Zaranis (2010) realised that the pre-school teachers encounter PCs more as a means of executing bureaucratic tasks and preparing their teaching rather than as an educational tool that is used during the educational process. In other words, they perceive PCs as independent devices without knowing the wider abilities as part of ICTs. These results can be explained mainly by the limited knowledge of the pre-school teachers for ICT and its usage in the school environment. Finally, the study by Kolerda, Sarafidou, and Spyridakis (2013) has shown that the vast majority of studies for the relationship between the Director of the nursery and the ICTs is oriented to the influence of the Director of the nursery in teaching and application of ICTs in the school unit and not in the degree of improvement of management skills of himself/herself in ICT towards a proliferative offer throughout the educational community (students, parents, teachers, supervisors). However, it was found that the need for very good knowledge and familiarity with ICT in the School Unit Director is immediate and dire. On the other hand, with what might be expected, this positive predisposition of teachers is not accompanied by relevant educational activity, which is most evident in the educational workers of the Kindergarten. The existence of the computer does not imply use (Papadimitriou, 2013) or, as rightly stated by O'Donnell, ICTs were introduced at school but fail to be part of the classroom (Papadimitriou, 2013).

By reviewing the recent studies it turns out that the nursery teachers modify their perspective and stance regarding the usage of new technologies in the nursery by passing from the denial and cautious stage to a positive approach. It seems that "the nursery school teachers understand the dynamics of technology, understand that their position and role is not in danger and by no means the dynamics of knowledge does decrease but in contrary the adoption of new mechanisms and production methods enhances and stabilizes their position" (Ntinas, 2010, p. 15) What triggered the choice of this particular research topic was the question of what happens in the specialty of nursery teachers and the realization, after conversation with colleagues of several specialties, that despite the teachers' training for the educational utilisation of ITCs, many of them still use the new technologies as an auxiliary tool; that is either as a presentational and projectional tool or as an information searching tool, worksheets in word, notes, or tests.

\section{Purpose of this Research - Research Questions}

For the above mentioned reasons it is important to explore the opinions and stances of the level of self-efficacy of the pre-school teachers in Greece in the usage and utilisation of ICTs in the learning process and nurseries' administration. To achieve this goal we will seek answers to the following research questions:

1) How does the entrance of ICTS in the administration of the nursery schools affect the opinions of the pre-school teachers for ICTs?

2) How does the utilisation of ICTs in the administration and preparation of teaching affect the opinions of the pre-school teachers for ICTs? 
3) How does the usage and utilisation of the ICTs in the administration of the nursery schools relate to the stance of the pre-school teachers for ICTs?

4) How does the usage and utilisation of ICTs in the learning process relate to the level of selfefficacy of the pre-school teachers?

5) How does the usage and utilisation of ICTs in the learning process relate to the position that the pre-school teachers hold in the school unit?

\section{Limitations of Research}

The sample of the study is not representative, as it is deemed to be small as it focuses on one region. Therefore it is impossible to extend the results to the general population of nursery teachers. However, a clear picture of the Greek nursery teachers has been given. For the study of the research questions a quantitative research has been designed. A qualitative methodology could offer a different perspective to these research questions. In particular, a qualitative approach could deepen in the subjects under study and give a different dimension to the subject.

\section{Research Methodology}

\section{Participants}

In this research, the participants were 131 nursery school teachers in the Primary Education Authority in the prefecture of Kavala. The sample of the study comprise of nursery school teachers and managers of single or multiple teacher nursery schools. We used a simple random sampling with a representative sample from the whole prefecture of Kavala (equal spread of urban, suburban, and rural areas). The prefecture of Kavala constitutes a representative example of an Education Authority since it consists of urban, suburban, and rural areas. The collection of the data from the general population of the Greek educators was impossible due to the size, cost, available time, and access inability.

We therefore collected data from a smaller team, which was a subgroup of the general population, so that the sample can be representative of the studied population (L. Cohen, Manion, \& Morrison, 2008). In order for the sample to be representative, the determination of the minimum number of participants was based on the principle that for the detection of a mean difference between two independent samples we need 64 participants in each group with an estimation error of $5 \%$ at a $95 \%$ level of significance (J. Cohen, 1991).

The prefecture's nursery teachers consisted of women aged 28-56 years old with work experience of 4-32 years in education. Finally, permission was requested and granted by the Education $\mathrm{Au}-$ thority and the nursery school teachers for conducting the study and their participation in it.

\section{Research Plan}

During the conducting of the research we adopted the approach of quantitative study and in particular the method of comparing the means of two independent groups in order to answer our research questions. We tested the means between the data that were collected from two different teams of teachers. The first group was comprised of pre-school teachers and the second group was comprised of pre-school teachers that hold the position of the manager in the nursery school. The reason behind the choice of the managers as objects of this study was their dual role in the school unit (teachers but also administrative and educational foremen/forewomen). Another reason for this choice was the responsibilities they bear for the qualitative upgrade and adjustment of the school unit that they manage to the new data of the educational process. In addition, their beliefs and plan of action are of vital importance for the formulation of the general policy that the school they manage will adopt. 
In particular, we studied whether there is a difference in the mean of the two groups between the opinions and level of self-efficacy concerning ICTs and the usage-utilisation of ICTs in the teaching and administration of the nursery school. The quantitative approach was chosen by using the personal preference and the familiarisation of the researcher with it but above all to the goals and questions that were set. This method was preferred since it is appropriate for the study of questions that regard the "how" of the phenomena (L. Cohen et al., 2008) and also is an economic way of collecting and analysing data for both the resources and the time constraints.

\section{Dependent Variables}

In the current research the dependent variables are the introduction of ICTs in the administration of the nursery schools and the usage and utilisation of ICTs in the learning process and administration.

\section{Independent Variables}

In the current research the independent variables are the opinions, the stances, the teachers' level of self-efficacy concerning ICTs and the position they hold in the school unit.

\section{Data Collection Tool}

As a data collection tool for the quantitative research we chose a questionnaire; such a method is relatively not expensive and has the ability to collect the answers of a large number of respondents. When creating the questionnaire a serious concern was the type of questions to be asked, the sequential order of the questions, and the creation of measurement scales. The Likert-type measurement scale was chosen with five possible answers in order to avoid neutral responses. The reason that we chose not to include a neutral answer to the biggest part of the questionnaire was in order to avoid the accumulation of such responses and thus facilitate the distribution of responses to negative and positive. The questions were of closed-end type. The design of the questionnaires was based on the Kartsioti and Roussos questionnaire (2010), which involved the construction of a psychometric measurement tool for the computer usage by teachers in teaching. The questionnaire was also based on the questionnaire by Kassotakis and Roussos (2006), which involved the construction of a Greek scale for the self-efficacy in computer use. We made the necessary modifications to make it suitable for the data collection that we wanted. The researcher also borrowed some ideas by a Vasileiou's and Mikropoulos' (2005) similar paper. (See the Appendix for a copy of the questionnaire.)

Finally, the researcher, by sending a cover letter, informed each teacher quickly and accurately for the research in which he/she will participate and emphasized the importance of their participation in order for them to respond responsibly and gave guidance on how the questions should be answered. Also, special attention was paid to the wording of the questions, with the help of a pilot research, so that the necessary improvements could be done in order to make it absolutely clear that the questions are easily understood.

\section{Reliability and Validity}

In order for the conclusions that were drawn from the data analysis of the questionnaire to be valid, it was necessary that the available data measured precisely the elements of interest and were directly related to the purpose and questions of the research. This concern was taken seriously into account during the planning of the questionnaire. So for this purpose we used the apparent validity of alternative survey methods, which means that an attempt was made to investigate the extent to which the questionnaire "appears" to measure what it claims to measure. 
For the above mentioned reason, the questionnaire under investigation was distributed to nonspecialist readers and their opinion was asked. This was done because it has been proven, as Zafeiropoulos (2005) mentions, that "a questionnaire that shows an apparent validity convinces the respondent for its value, consistency and purpose, therefore it is answered with fewer problems regarding refusals, resentment of the respondent, etc." (page 122).

Because the apparent validity appears to be of minor importance in comparison to other forms of validity (Zafeiropoulos, 2005), an attempt to control the content validity was made so that the questions meet and adequately describe the content of the phenomenon that the questionnaires were to investigate. Finally, there was a correlation between the scale we created and a corresponding one measuring similar features (convergent validity). For the above reason, along with the scale we made, we provided the scale used for a similar study by Kassotakis and Roussos (2006) and Kartsioti and Roussos (2010).

However, there were some factors that were impossible to control and, therefore, could have shaken the validity and reliability of the measurements. Therefore, the accuracy of the responses and the honesty of the respondents cannot be ensured. For this reason and with the help of the pilot survey we used the internal consistency reliability in order to evaluate the homogeneity of the scale's questions. The scale was applied only once; for the responses the Cronbach's alpha coefficient was used which was $a=0.78$, with an acceptable limit being $a=0.70$. The reliability of repeated measurements was also used in order to evaluate the stability of the responses. For this purpose the scale was applied twice to the same person under the same conditions at an interval of one week and a correlation of the two scores, was calculated which was found to be $r=0.77$, with an acceptable limit of the coefficient (Pearson's correlation coefficient) to be $r=0.70$. Lastly, the representativeness of the sample is not altered, as there was a very high response rate since only 3 out of 131 respondents were absent.

\section{Procedure}

The conduct of the research was focused on the Kavala prefecture. The population concerning the investigation was the nursery school teachers of the Primary Education Authority of Kavala. The procedure adopted for the research consists of the following stages.

a) The first stage, August 2014, was the selection of the sample on which the research was conducted. More on the selection of the sample was mentioned in the previous paragraph.

b) After the creation of the questionnaire, December 2014, and for checking of the apparent validity, the questionnaires were distributed to non-specialised readers and their opinion was asked, January 2015.

c) After checking of apparent validity done a pilot study, March - April 2015. A pilot study was conducted in a small portion of the sample. The initial questionnaires were given for trial to seven trained teachers who could check for errors, ambiguities, etc. Problems such as the wording of the questions were addressed before the questionnaires were in their final form and ready for distribution.

d) After the pilot study, distribution of the questionnaires to individuals of the sample, May 2015. The interviewer, after getting permission from the Education Authority, sent out the questionnaires electronically to nursery schools asking the permission of the nursery school teachers. For each questionnaire the first page constitutes a cover letter which includes information about the survey, instructions for completing the questionnaire; it also stresses the importance of the participation of the respondent in the survey. This last part was expected to increase the probability of response from the participants whilst the clear instructions contribute to the validity of the research (Javeau, 2000). 
e) Collection of completed questionnaires, May 2015. Participants were given a deadline of two weeks to complete the questionnaire which is considered a long enough period so that they don't feel pressed to respond. Finally, the researcher collected the completed questionnaires via Google drive.

\section{Data Processing}

The processing of the data obtained was done with the statistical package SPSS v20. In the first part of the analysis the descriptions of each variable were presented. The data were depicted by appropriate tables and charts so that the profile of the participants and their responses could be outlined in order to be easily perceived by the researcher and the reader. Then the data analysis was conducted by using statistical inference. For each group, the sample averages were calculated and then for the study of the relationship we applied a T - test for independent samples; however, we first checked that the data from both groups were drawn from populations that were normally distributed and had equal variances. The critical value for a two tailed test of statistical significance level $\alpha=0.05$ and the appropriate degrees of freedom (df) was found and compared to the $t$ value; then the results were assessed whether they were statistically significant (Emvalotis, Katsis, \& Sideridis, 2006; (Roussos \& Tsaousis, 2011). Finally, the conclusions were drawn based on the data so that the questions set could be answered.

The questionnaires were assigned a serial number and were encoded. The questions were numbered for each part of the questionnaire separately and so it was easy to present the results in tables. The scales (strongly disagree, disagree, neither agree nor disagree, agree, strongly agree, also, never, rarely, more than once a month, more than once a week, every day and too much, enough, a bit, not at all) received the following values: strongly disagree $=1$, disagree $=2$ neither agree nor disagree $=3$, agree $=4$, strongly agree $=5$. The next scale was never $=0$, rarely $=1$, more than once a month $=2$, more than once a week $=3$, every day $=4$ and respectively too much $=4$, a lot $=3$ Fairly $=2$ Bit $=1$ None $=0$.

By using these scales, the frequencies of responses and the average of responses were calculated (Javeau, 2000). To facilitate the processing, the data from the questionnaires were encoded. Then we created a worksheet with the encoded data in which each row corresponded to an individual questionnaire (participant) and each column to a question or sub-question.

\section{Results of the Questionnaires' Processing}

\section{Results of the Demographics of the Questionnaires}

The sample of the survey consisted of 128 teachers. Their average age was 43.68 with standard deviation of 6.86. The whole sample was consisted of women. Concerning the level of their studies, as shown in the diagram in Figure 1, the majority of the participants $(82.98 \%)$ have a second degree and $17.02 \%$ are master's holders. 


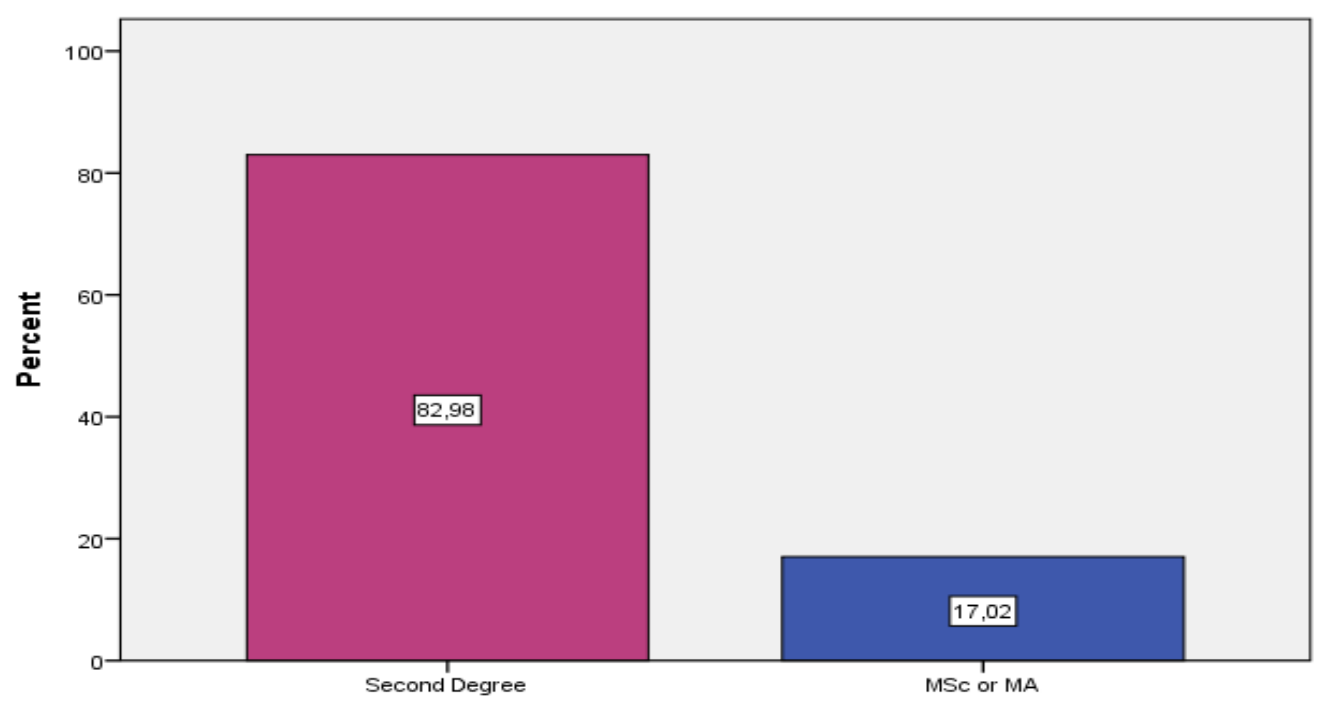

Figure 1. Diagram of the distribution of the survey respondents with respect to their level of studies

Regarding the educational experience of the teachers, the average employment experience was 16.07 with a standard deviation of 6.85 . In addition, $43.8 \%$ hold managerial positions (Head / Director) and 56.2\% do not, as shown in the diagram in Figure 2.

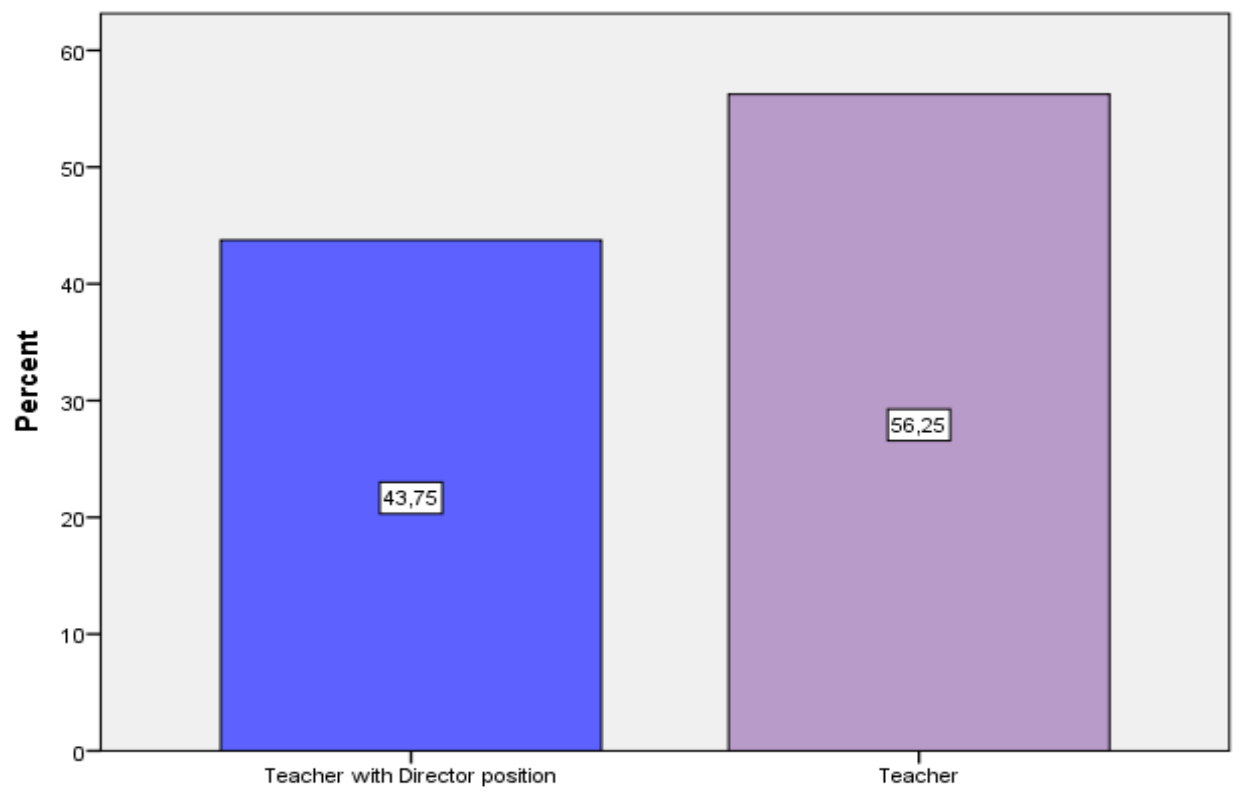

Figure 2. Diagram of the distribution of the survey respondents with respect to the position they hold in their service

Regarding the area of the school $42.19 \%$ of the schools are in urban areas, $33.59 \%$ are in suburban and $24.22 \%$ are in rural areas, as shown in the graph in Figure 3. 


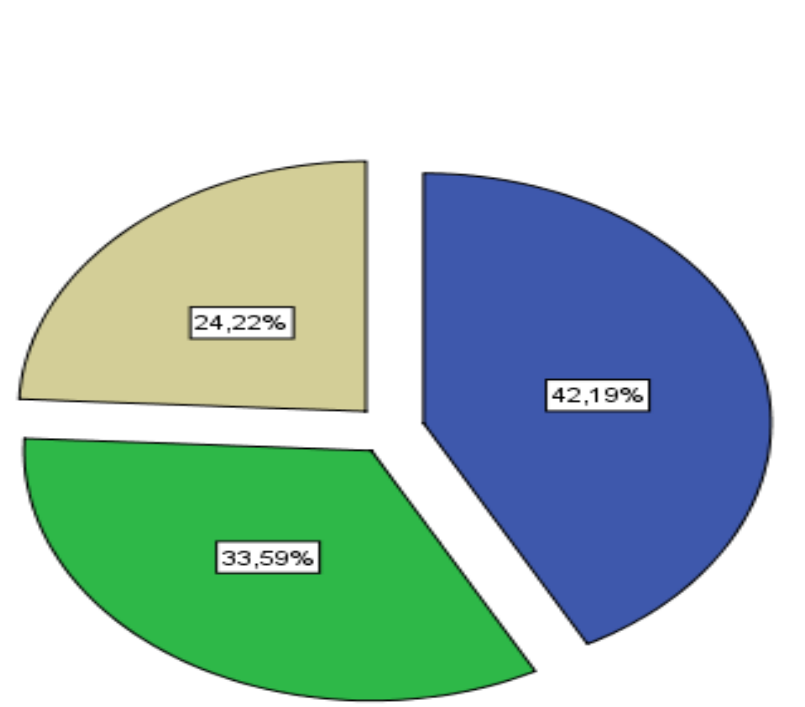

Figure 3. Pie chart of the survey respondents with respect to the school's area

\section{Analysis of the Responses with Respect to the Position They Hold (Administrative or Otherwise) in the Nursery School Compared to the Components of Research}

The components of the survey are:

- Entry of ICTs in the management of the nursery schools,

- Utilization of ICTs in the management and preparation of the teaching practice,

- Investigation of the stance of the participants towards the use and utilisation of ICTs in the management of nursery schools,

- Investigation of the self-efficacy of the teachers in the use and exploitation of ICTs in the learning process,

- Investigation of the extent of use and exploitation of ICTs in the learning process of a nursery school.

All the above are components of the study "investigation of the opinions, stances, and the level of self-efficacy in ICTs of the Greek nursery school teachers in the usage and the utilisation of ICTs in the learning process and the administration of nurseries." The position that the teachers held (administrative or not) was studied in relation to the components of the research: introduction of ICTs in the management of nursery schools, usage of ICTs in the management and preparation of teaching, investigation of the stances of the participants in the usage and utilisation of ICTs in the management of nursery schools, the exploration of the self-efficacy of teachers in the use and utilisation of ICTs in the learning process, and finally to investigate the degree of use and utilisation of ICTs in the learning process of a nursery school.

\section{Relationship between the Opinions of Nursery School Teachers in the Introduction of ICTs in the Management of Nursery Schools and the Position (Administrative or Not) They Hold}

To investigate the relationship between the position and the opinions in the introduction of ICTs in the management of nursery schools the data were analysed by using the $\mathrm{T}$ - test for independent samples (administrative position, not an administrative position). The results showed statistically significant differences in the position of nursery school teachers regarding the opinions in 
the introduction of the ICTs in the management $\mathrm{t}(126)=3.496, \mathrm{p}<0,05$, with holders of a management position $(\mathrm{M}=1.7903, \mathrm{SD}=0.199)$ to consider more positive opinions in the introduction of ICTs in the management of nursery schools than teachers with no managerial positions $(\mathrm{M}=$ $1.6610, \mathrm{SD}=0.214)$.

\section{Relationship between the Opinions of Preschool Teachers for the Utilisation of ICTs in the Management and Preparation of Teaching and the Position They Hold (Administrative or Not)}

To investigate the relationship between the positions the teachers hold and their opinion for the utilisation of ICTs in the management and preparation of teaching, the analysis was conducted by using the $\mathrm{T}$ - test for independent samples (administrative position, not an administrative position). The results showed statistically significant differences regarding the position of pre-school teachers and the use and the utilisation of ICTs in the management and preparation of teaching $\mathrm{t}(113,025)=5.509, \mathrm{p}<0,05$, with holders of management positions $(\mathrm{M}=2.5921, \mathrm{SD}=0.463) \mathrm{uti}-$ lising ICTs more in the management and preparation of teaching, utilisation of e-mail tools, text editors, management information systems for the logistics of the nursery school and educational software, electronic encyclopaedias, search engines and tools for the preparation of teaching than teachers with no management position $(\mathrm{M}=1.8859, \mathrm{SD}=0.867)$.

\section{Relationship between the Stances of Preschool Teachers in the Use and Utilisation of ICTs in the Management of Nursery Schools and the Position They Hold (Administrative or Not)}

To investigate the relationship between the position and stances of pre-school teachers in the use and utilisation of ICTs in the management of nursery schools the analysis was conducted by using the $\mathrm{T}$ - test for independent samples (administrative position, not an administrative position). The results showed statistically significant differences regarding the position and the stances of preschool teachers in the use and utilisation of the ICTs in the management of nursery schools $\mathrm{t}(114,538)=3,806, \mathrm{p}<0,05$, with holders of management positions $(\mathrm{M}=2.5561, \mathrm{SD}=0.424)$ having a positive attitude towards the use and utilisation of the ICTs in the management of nursery schools, using and utilising e-mail tools, text editors and management information systems for the logistics of the nursery school in comparison to teachers with no managerial positions ( $\mathrm{M}=$ $2.1488, \mathrm{SD}=0.771)$.

\section{Relationship between the Level of the Self-efficacy of Preschool Teachers to the Use and Utilisation of ICTs in the Learning Process and the Position They Hold (Administrative or Not)}

To investigate the relationship between the position and the level of the self-efficacy of preschool teachers to the use and utilisation of the ICTs in the learning process the analysis was conducted by using the $\mathrm{T}$ - test for independent samples (administrative position, not an administrative position). The results showed no statistically significant differences in the position of preschool teachers and the degree of their self-efficacy to the use and utilisation of ICTs in the learning process, with both having a very high degree of self-efficacy in the use and utilisation of educational software, electronic encyclopaedias, search engines, presentational tools, and tools for the learning process. 


\section{Relationship between the Degree of Use and Utilisation of ICTs in the Learning Process by Preschool Teachers and the Position They Hold (Administrative or Not)}

To investigate the relationship between the position and the degree of use and utilisation of ICTs in the learning process by preschool teachers the analysis was conducted by using the $\mathrm{T}$ - test for independent samples (administrative position, not an administrative position). The results showed statistically significant differences in the position of preschool teachers and the degree of use and utilisation of ICTs in the learning process $\mathrm{t}(122,342)=4.202, \mathrm{p}<0,05$, with holders of management position $(\mathrm{M}=2.7668, \mathrm{SD}=0.586)$ having a higher degree of use and utilisation of ICTs in the learning process, using and utilising educational software's, electronic encyclopaedias, search engines, presentational tools and tools for learning process than teachers with no management position $(\mathrm{M}=2.2110, \mathrm{SD}=0.904)$.

\section{Conclusions}

The basic conclusions of the current research are focusing on the following.

One of the main goals of this research was the investigation between the opinions of pre-school teachers for the introduction of ICTs in the management of the nursery schools and the position (managerial or not) that they hold in the school unit.

The research showed that the teachers that hold a managerial position have a more positive opinion for the introduction of ICTs in the management of the nursery schools. Also, the investigation of the relationship between the opinions of the pre-school teachers for the utilisation of ICTs in the management and the preparation of teaching and the position (managerial or not) the teachers have in the school unit has shown that the teachers that have a managerial position utilise ICTs in the management and preparation of teaching more by using mail tools, text editors, logistics for the managerial support of the nursery school and the educational software, electronic encyclopaedias, search machines and tools for the preparation of teaching.

The investigation of the relationship between the stance of the pre-school teachers in the use and utilisation of ICTs in the management of the nursery schools and the position (managerial or not) that they have in the school unit has shown that the teachers that have a managerial position have more positive stance in the use and utilisation of ICTs in the management of the nursery schools by using and utilising mail tools, text editors, logistics for the managerial support of the nursery school. Regarding the investigation of the relationship between the level of self-efficacy of the pre-school teachers in the use and utilisation of ICTs in the learning process and the position (managerial or not) that the teachers have in the school unit, the research has shown that both groups have a very high level of self-efficacy in the use and utilisation of the education software, electronic encyclopaedias, search engines, presentational tools and tools used for the learning process.

Lastly, the investigation of the degree of the usage and utilisation of ICTs in the learning procedure by pre-school teachers and the position (managerial or not) that they hold in the school unit has shown that the teachers that hold a managerial position also have a higher degree in the usage and utilisation of ICTs in the learning process by using and utilising educational software, electronic encyclopaedias, search engines, presentational tool and tools that help in the learning process. 


\section{Discussion of the Results}

In the sensitive area of education, where all society's hopes for progress and development are reflected, the qualitative upgrade of the educational system is the desideratum.

The Ministry of Education, by understanding the needs and responding to the requirements of the Lisbon Treaty, organized and ran teachers' trainings in new technologies with the main goal of the trainings being for the trainees to understand the conditions and the abilities of the pedagogical utilisation of ICTs in education for the upgrade in the educational procedure and learning and that the teachers can use the abilities offered by ICTs effectively for their active participation of the educators and the students in learning progress. In addition, the teachers should obtain the total supervision for the current educational software and the current general and specific tools (internet, word editor, excel spreadsheets) so that they can utilise the introduction of ICTs in the educational practice. Furthermore, they have to be in position to use educational software which is specific to their specialty, general or specific tools, to realize the importance and the role of the educational activity for the application of ICTs in the classroom and also to understand the principles of the design of an educational activity so that they can introduce it to the educational practice. Lastly they should be able to recognize the basic principles of organization and management of ICTs in the classroom.

The current research has shown the same as the record of recent surveys, that the pre-school teachers amend their opinions and stances regarding the usage of new technologies in the nursery school by going through the phase of denial and cautiousness to a positive approach. It seems that the nursery school teachers understand the dynamics of technology, understand that their position and their role is not threatened and that under no circumstances the dynamics of their knowledge it's belittled; on the contrary, with the adoption of new mechanisms and processes it is strengthened and stabilized. However, a slight precedence to such development there is for the teachers of pre-school education that hold a managerial position. Lastly, the results of the current research have brought to the surface a very interesting topic which is that of the educational support of the effort of the teachers to utilise ICTs in teaching, by introducing a framework of educational support at the level of the Educational Authority by institutionalising appropriately trained teachers who will induce responsibility in the education leadership of their colleagues and the embedding of ICTs in the educational process.

\section{References}

Bandura, A. (1997). Social learning theory. Englewood Cliffs, New Jersey: Prentice-Hall Inc.

Christodoulou-Gliaou, N., \& Gourgiotou, E. (2009). Attitudes of kindergarten teachers of public and private kindergartens to use the computer in the preschool classroom. Inspection of Educational Affairs, $125,148-165$.

Cohen, J. (1991). Quantitative methods in psychology. A power primer. Psychological Bulletin, 112(1), 155 - 159. American Psychological Association

Cohen, L., Manion, L., \& Morrison, K. (2008). Research methods in education. New York: Routledge

Compeau, D., \& Higgins, C. (1995). Computer self-efficasy: Development of a measure and initial test. Management Information System Quarterly, 189-211.

EAITY (2009), Teacher Training in support of ICT in teaching practice, level B. Retrieved February 2013 from http://b-epipedo2.cti.gr/

Emvalotis, A., Katsis, A., \& Sideridis, G. (2006). Statistical educational research methodology. Ioannina (in Greek). 
Gialamas, B., Zaranis, N., \& Tsara, E. (2009). Opinions of kindergarten for the use of computer in mathematics in kindergarten. 5th Hellenic Conference of teachers on ICT Utilization of Information Technologies and Communication in Teaching Practice, Syros.

Goti, E., \& Ntinas, K. (2010). Kindergarten teachers and computers: A path ten years. Proceedings of the 3rd National Conference Et.E.A.D. The teacher and his work. Past, present, future, Vol. B, 875-892

Javeau, C. (2000). Survey using questionnaires. The manual of the good researcher. Athens: Tipothito (in Greek).

Jimoyiannis, A. (2008). Factors determining teachers' beliefs and perceptions of ICT in education. In A. Cartelli \& M. Palma (Eds.), Encyclopedia of information communication technology, pp. 321-334, Hershey, PA: IGI Global

Jimoyiannis, A., \& Komis, B. (2006). ICT in education: Exploring the views of teachers of secondary education. $5^{\text {th }}$ Greek Conference with International participation "Information Technologies and Communication in Education", 829-836, Thessaloniki.

Kartsioti, Th. \& Roussos, P. (2010). Construction psychometric measurement tool of computer use by teachers for teaching. Retrieved from http://old.psych.uoa.gr/ roussosp//gr/index.htm

Kassotakis, S \& Roussos, P. (2006). The Greek-efficacy scale in computer usage. Retrieved from http://www.etpe.gr/custom/pdf/etpe1160.pdf

Kolerda, S., Sarafidou, K., \& Spyridakis, A. (2013). The need for training of school director in ICT. Educational Science Magazine “Ekp@ideftikos cycle”, 1(1), 83-185.

Lovari, D., \& Charalampous, K. (2006). Comparison of the results for information and communications technologies using conventional media in teaching and learning processes in a particular subject area of early childhood education. Technologies in Preschool Education. 9th Conference of Cyprus Pedagogical Association.

Mainas, D. (2009) Teacher training in the use and exploitation of ICT the educational teaching process: An evaluation attempt. Retrieved from www.epyna.eu/agialama/synedrio syros 5/eisigiseis/706 mainas c.doc

Ntinas, K. (2010). New technologies and language teaching: An account- emerging perspectives. 3rd National Conference 'Achilles Tzartzani' for the Greek Language, Tirnavos. Accessed from: http://www.larissa.gr/main.aspx?catid=81\&year $=2010$

Oikonomidis, B., \& Zaranis, N. (2010) The use of the computer in preschool education: Interviews with nursery school teachers. Proceedings of the 7th Pan-Hellenic Conference with International participation "The ICT in Education", Volume II, University of Peloponnese, Corinth, 545- 552.

Papadimitriou, S. (2013). Views of kindergarten teachers for the implementation of a research evaluation tool infants in computer skills. thesis, Thessaloniki: Aristotle University

Passa, S. (2010). The efficacy study of the training program for primary school teachers in using ICT in the educational teaching process (B-Epipedo), through the views of learners and their trainers. The case of the county of Preveza and Arta. Diploma Thesis, Patra: HOU.

Petrogiannis, K. (2010). The relationship between perceived preparedness for computer use and other psychological constructs among kindergarten teachers with and without computer experience in Greece. Journal of Information Technology Impact, 10, 99-110.

Roussos, P., \& Tsaousis, Y. (2011). Statistics for the behavioral sciences using SPSS. Athens: Topos.

Sim, J. CH., \&Theng, L.B. (2007). Teachers' perceptions of the use of ICT as an instructional tool in mathematics and science. Retrieved from http://ictl.intimal.edu.my/ict12007/proceeding/Full_Paper/1A-03-Paper\%2069\%20(Malaysia).pdf

Trapsioti, A. (2010). One year after the training: Teachers utilize new knowledge and skills in the classroom. Retrieved from http://mag.e-diktyo.eu/?cat=51 
Vasileiou, E., \& Mikropoulos, T. (2005). Learning activities with a computer in kindergarten. $3^{\text {rd }}$ Greek Conference of Teachers for ICT (596-604, volume B). Athens: New Technologies.

Zafeiropoulos, K. (2005). How we create a scientific paper? Scientific research and essay writing. Athens: KRITIKI (in Greek).

Zetta, B. Papaconstantinou, S. \& Apostolidis, G. (2009) Evaluating the B-level training for the use of ICT in educational process to philologists of Serres, Drama and Kavala. Retrieved from

http://www.etpe.eu/new/custom/pdf/etpe1451.pdf 


\section{Appendix}

\section{QUESTIONNAIRE}

School area

Urban

Suburban

Rural

\section{A. DEMOGRAPHICS}

1. Gender: Male Female

2. Age:

3. Years in total in education service:

4. Position you hold in kindergarten are working:

Administrative position (Head / Director)

$\square$ Non-management position (Teacher)

5. Qualifications / Knowledge Level:

Bachelors Degree

Second Bachelors Degree

$\checkmark$ Master Title

$\square$ Doctoral Title

\section{B. INTRODUCTION OF ICT IN ADMINISTRATION OF KINDERGARTENS}

1. Do you have computer knowledge?

$$
\begin{aligned}
& \square \text { YES } \\
& \square \text { NO }
\end{aligned}
$$

2. If you have knowledge of computer, note:
a. Participation in training seminars
b. self-education

3. Do you use a computer in the classroom?

\section{$\square$ YES \\ $\square \mathrm{NO}$}

4. For which activity are you using ICT to conduct administrative work in your nursery? (Note which of these apply).

\begin{tabular}{|l|l|l|}
\hline a. & Email & \\
\hline b. & Typing - Printing documents & \\
\hline c. & Update on interactive portal (my school) & \\
\hline d. & Computerization of School & \\
\hline e. & Electronic Protocol & \\
\hline
\end{tabular}


5. Have you received some kind of training in new technologies?

$\square$ YES

$\square \mathrm{NO}$

6. Note the operator who conducted your training in new technologies.

\begin{tabular}{|l|l|}
\hline University / Technological Institute & \\
\hline Ministry of Education & \\
\hline Municipality (City / Region) & \\
\hline School Director / Teachers' Association & \\
\hline
\end{tabular}

7. Do you agree that education in information and communication technologies should be continuous?

$$
\begin{aligned}
& \square \text { YES } \\
& \square \text { NO }
\end{aligned}
$$

8. Which of the following reasons do you think that make education in information and communication technologies continued?
a. Greater familiarity with computer
b. The constant evolution of technology
c. Utilization of Computer in Teaching
d. Strengthening of professional qualifications

9. How necessary is training in the use of new technologies?

\begin{tabular}{|l|l|l|l|l|}
\hline Very Much & Usually & Sometimes & Seldom & No, never \\
\hline & & & & \\
\hline
\end{tabular}

10. How necessary is training in the use of new technologies in connection with your teaching subject?

\begin{tabular}{|l|l|l|l|l|}
\hline Very Much & Usually & Sometimes & Seldom & No, never \\
\hline & & & & \\
\hline
\end{tabular}

11. What extent do you think that training met your training needs?

\begin{tabular}{|l|l|l|l|l|}
\hline Very Much & Usually & Sometimes & Seldom & No, never \\
\hline & & & & \\
\hline
\end{tabular}

12. Did you make use and to what extent the knowledge acquired from the trainings in everyday practice in kindergarten?

\begin{tabular}{|l|l|l|l|l|}
\hline Very Much & Usually & Sometimes & Seldom & No, never \\
\hline & & & & \\
\hline
\end{tabular}


13. How often do you think that training in ICT should be done?

\begin{tabular}{|l|l|l|}
\hline Annual & Every two years & Every four years \\
\hline & & \\
\hline
\end{tabular}

14. What time period do you consider that a training program for the use of ICT in the learning process should have?

\begin{tabular}{|l|c|c|}
\hline $\begin{array}{c}\text { Short duration } \\
\text { (up to 60 hours) }\end{array}$ & $\begin{array}{c}\text { Average length } \\
(120-180 \text { hours })\end{array}$ & $\begin{array}{c}\text { Long } \\
\text { (300-500 hours) }\end{array}$ \\
\hline & & \\
\hline
\end{tabular}

15. Which form do you wish to have for your service training?

\begin{tabular}{|l|l|l|}
\hline a. & Educational workshops & \\
\hline b. & Intensive Seminars & \\
\hline c. & Long training programs & \\
\hline
\end{tabular}

16. If you have not received a training on the ICT, which of the following is the main reason?

\begin{tabular}{|l|l|l|}
\hline a. & Training didn't gave importance to the specific issue & \\
\hline b. & $\begin{array}{l}\text { Failure to follow training (lack of time, transition } \\
\text { difficulties, family responsibilities) }\end{array}$ & \\
\hline c. & Monitoring training programs is a "waste of time" & \\
\hline d. & $\begin{array}{l}\text { The "ICT" does not concern me as a matter of train- } \\
\text { ing }\end{array}$ & \\
\hline
\end{tabular}

\section{USE OF ICT IN ADMINISTRATION OF KINDERGARTENS}

1. How often do you use the computer to the kindergarten for administrative actions?

\begin{tabular}{|l|l|l|l|l|}
\hline Very Much & Usually & Sometimes & Seldom & No, never \\
\hline & & & & \\
\hline
\end{tabular}

2. Do you agree that information and communication technologies should be used in the administration of the kindergarten?

\section{$\square$ YES}

$\square \mathrm{NO}$ 
3. What extent do you agree that the use of computer management is necessary:

\begin{tabular}{|l|l|l|l|l|}
\hline Very Much & Usually & Sometimes & Seldom & No, never \\
\hline & & & & \\
\hline
\end{tabular}

4. How often do you use new technologies in kindergarten for each of the following cases of administrative actions?

\begin{tabular}{|l|l|l|l|l|l|}
\hline & $\begin{array}{c}\text { Very } \\
\text { Much }\end{array}$ & Usually & Sometimes & Seldom & No, never \\
\hline File management & & & & & \\
\hline Contact (e-mail) & & & & & \\
\hline $\begin{array}{l}\text { Typing - printing docu- } \\
\text { ments }\end{array}$ & & & & & \\
\hline $\begin{array}{l}\text { Update on interactive por- } \\
\text { tal (my school) }\end{array}$ & & & & & \\
\hline Computerization of school & & & & & \\
\hline Electronic Protocol & & & & & \\
\hline
\end{tabular}

5. Are you reviewing the introduction of the ICT in the administration of kindergarten ?

\begin{tabular}{|l|l|l|l|l|}
\hline Very Much & Usually & Sometimes & Seldom & No, never \\
\hline & & & & \\
\hline
\end{tabular}

\section{INVESTIGATION OF STAGING OF PARTICIPANTS IN THE ADMINISTRATIVE PROCEDURE KINDERGARTENS}

1. To what extent do you consider that the use of ICT contributes to the efficient running of the administrative work in your nursery?

\begin{tabular}{|l|l|l|l|l|}
\hline Very Much & Usually & Sometimes & Seldom & No, never \\
\hline & & & & \\
\hline
\end{tabular}

2. For which of the following reasons do you believe that it is necessary to use ICT in the efficient running of the administrative work in your nursery?

\begin{tabular}{|l|l|l|}
\hline a. & Time Saving & \\
\hline b. & Ability to better Organization & \\
\hline c. & Cost Reduction & \\
\hline
\end{tabular}


3. What extent do you consider that you are satisfied from your existing technical equipment regarding the use of ICT in the efficient running of the administrative work in your nursery?

\begin{tabular}{|c|c|c|c|c|}
\hline Very Much & Usually & Sometimes & Seldom & No, never \\
\hline & & & & \\
\hline
\end{tabular}

4. In which of the following areas / activities related to the administrative work in your nursery, the use of ICT contributes more?

\begin{tabular}{|l|l|l|l|l|l|l|}
\hline & \multicolumn{1}{|l|}{$\begin{array}{c}\text { Very } \\
\text { Much }\end{array}$} & Usually & Sometimes & Seldom & $\begin{array}{c}\text { No, nev- } \\
\text { er }\end{array}$ \\
\hline a. & $\begin{array}{l}\text { The stream-lining of } \\
\text { administrative func- } \\
\text { tions }\end{array}$ & & & & & \\
\hline b. & $\begin{array}{l}\text { The easier and more } \\
\text { friendly to the user } \\
\text { management of } \\
\text { standardized man- } \\
\text { agement procedures }\end{array}$ & & & & & \\
\hline c. & $\begin{array}{l}\text { The faster and easi- } \\
\text { er communication } \\
\text { between schools }\end{array}$ & & & & & \\
\hline d. & $\begin{array}{l}\text { The transparency of } \\
\text { administrative ac- } \\
\text { tions }\end{array}$ & & & & & \\
\hline
\end{tabular}

\section{E. LOOKING INTO THE SELF-EFFICACY OF TEACHERS IN THE USE AND EX- PLOITATION OF ICT IN THE LEARNING PROCESS.}

In the table below please circle one of the numbers $1-5$, where $1=$ strongly disagree, $2=$ disagree, $3=$ neither agree nor disagree, $4=$ agree, $5=$ strongly agree.

I feel that I can:

\begin{tabular}{|c|c|c|c|c|c|}
\hline Organize files stored on the computer in folders & 1 & 2 & 3 & & \\
\hline Write a text on the computer & 1 & 2 & 3 & 4 & 5 \\
\hline $\begin{array}{l}\text { Handle objects (such as buttons, icons, windows, scroll bars, } \\
\text { menus, drop-down lists, etc.) with ease }\end{array}$ & 1 & 2 & 3 & & \\
\hline $\begin{array}{l}\text { Make changes to print a file in terms of printing quality, the } \\
\text { number of pages, number of copies, print specific pages etc. }\end{array}$ & 1 & 2 & 3 & & 5 \\
\hline $\begin{array}{l}\text { Face simple problems (for example, to connect a device that } \\
\text { has been disconnected, install a printer, etc.) on the computer }\end{array}$ & 1 & 2 & 3 & & \\
\hline $\begin{array}{l}\text { Format a text document (eg, to change the size, font color, par- } \\
\text { agraph formatting, etc.) in the } \mathrm{P} / \mathrm{C}\end{array}$ & 1 & 2 & 3 & & 5 \\
\hline Download and read the attachments containing an email & 1 & 2 & 3 & & 5 \\
\hline Forward to other recipients an email message that I re & 1 & 2 & 3 & & 3 \\
\hline
\end{tabular}




\begin{tabular}{|l|lllll|}
\hline $\begin{array}{l}\text { Search for information on a topic on the Internet (Internet) us- } \\
\text { ing search engines }\end{array}$ & 1 & 2 & 3 & 4 & 5 \\
\hline Download a file from the Internet (Internet) & 1 & 2 & 3 & 4 & 5 \\
\hline
\end{tabular}

\section{F. LOOKING INTO THE DEGREE OF USE AND DEVELOPMENT OF ICT IN LEARN- ING PROCESS OF A KINDERGARTEN}

1. How often do you use the computer in the learning process?

\begin{tabular}{|c|c|c|c|c|}
\hline Very Much & Usually & Sometimes & Seldom & No, never \\
\hline & & & & \\
\hline
\end{tabular}

2. Do you agree that information and communication technologies should be used in kindergarten?

$$
\begin{aligned}
& \square \text { YES } \\
& \square \text { NO }
\end{aligned}
$$

3. What extent do you agree that it is necessary the use of the computer in your teaching?

\begin{tabular}{|l|l|l|l|l|}
\hline Very Much & Usually & Sometimes & Seldom & No, never \\
\hline & & & & \\
\hline
\end{tabular}

4. If you agree to the use of ICT in Kindergarten, note the extent to which you agree that new technologies can be used in each of the following cases:

\begin{tabular}{|l|l|l|l|l|c|}
\hline & Very Much & Usually & Sometimes & Seldom & $\begin{array}{c}\text { No, } \\
\text { never }\end{array}$ \\
\hline File management & & & & & \\
\hline Contact (e-mail) & & & & & \\
\hline In teaching (general) & & & & & \\
\hline Update of the teacher & & & & & \\
\hline
\end{tabular}

5. If you disagree with the use of ICT in Kindergarten, note the reason why this is the case for you:

\begin{tabular}{|l|l|}
\hline I do not consider their use necessary & \\
\hline There are not given instructions on the use of ICT in the curriculum & \\
\hline Requiring additional time for their use & \\
\hline I feel insecure in relation to the use of ICT in Kindergarten & \\
\hline
\end{tabular}


6. Methods and frequency of use of the computer from the educator for the preparation of teaching:

\begin{tabular}{|l|l|l|l|l|l|}
\hline & $\begin{array}{c}\text { Very } \\
\text { Much }\end{array}$ & Usually & Sometimes & Seldom & No, never \\
\hline $\begin{array}{l}\text { In the Internet to find infor- } \\
\text { mation and teaching material } \\
\text { (Visiting blogs, wikis) }\end{array}$ & & & & & \\
\hline $\begin{array}{l}\text { Educational software of the } \\
\text { Pedagogical Institute }\end{array}$ & & & & & \\
\hline $\begin{array}{l}\text { Electronic libraries for finding } \\
\text { information }\end{array}$ & & & & & \\
\hline $\begin{array}{l}\text { Text processors (Word) for } \\
\text { course notes }\end{array}$ & & & & & \\
\hline $\begin{array}{l}\text { Spreadsheets (Excel) for ac- } \\
\text { tivities }\end{array}$ & & & & & \\
\hline PowerPoint for presentations & & & & & \\
\hline Multimedia, video, photos, & & & & & \\
\hline $\begin{array}{l}\text { Online collaborative tools } \\
\text { (example: Wikipedia) }\end{array}$ & & & & & \\
\hline $\begin{array}{l}\text { Graphics, audiovisual materi- } \\
\text { al (eg video, DVD, Youtube) }\end{array}$ & & & & & \\
\hline
\end{tabular}

7. Methods and frequency of computer use by the teacher for teaching:

\begin{tabular}{|l|l|l|l|l|l|}
\hline & $\begin{array}{c}\text { Very } \\
\text { Much }\end{array}$ & Usually & Sometimes & Seldom & $\begin{array}{c}\text { No, nev- } \\
\text { er }\end{array}$ \\
\hline $\begin{array}{l}\text { For finding information on the } \\
\text { Internet (Visiting blogs, wikis) }\end{array}$ & & & & & \\
\hline $\begin{array}{l}\text { For teaching subjects (Lan- } \\
\text { guage, Mathematics, B. Sci- } \\
\text { ences, etc.) with appropriate } \\
\text { internet educational software }\end{array}$ & & & & & \\
\hline $\begin{array}{l}\text { For teaching subjects (Lan- } \\
\text { guage, Mathematics, B. Sci- } \\
\text { ences, etc.) with original edu- } \\
\text { cational software that the } \\
\text { teacher prepares }\end{array}$ & & & & & \\
\hline
\end{tabular}




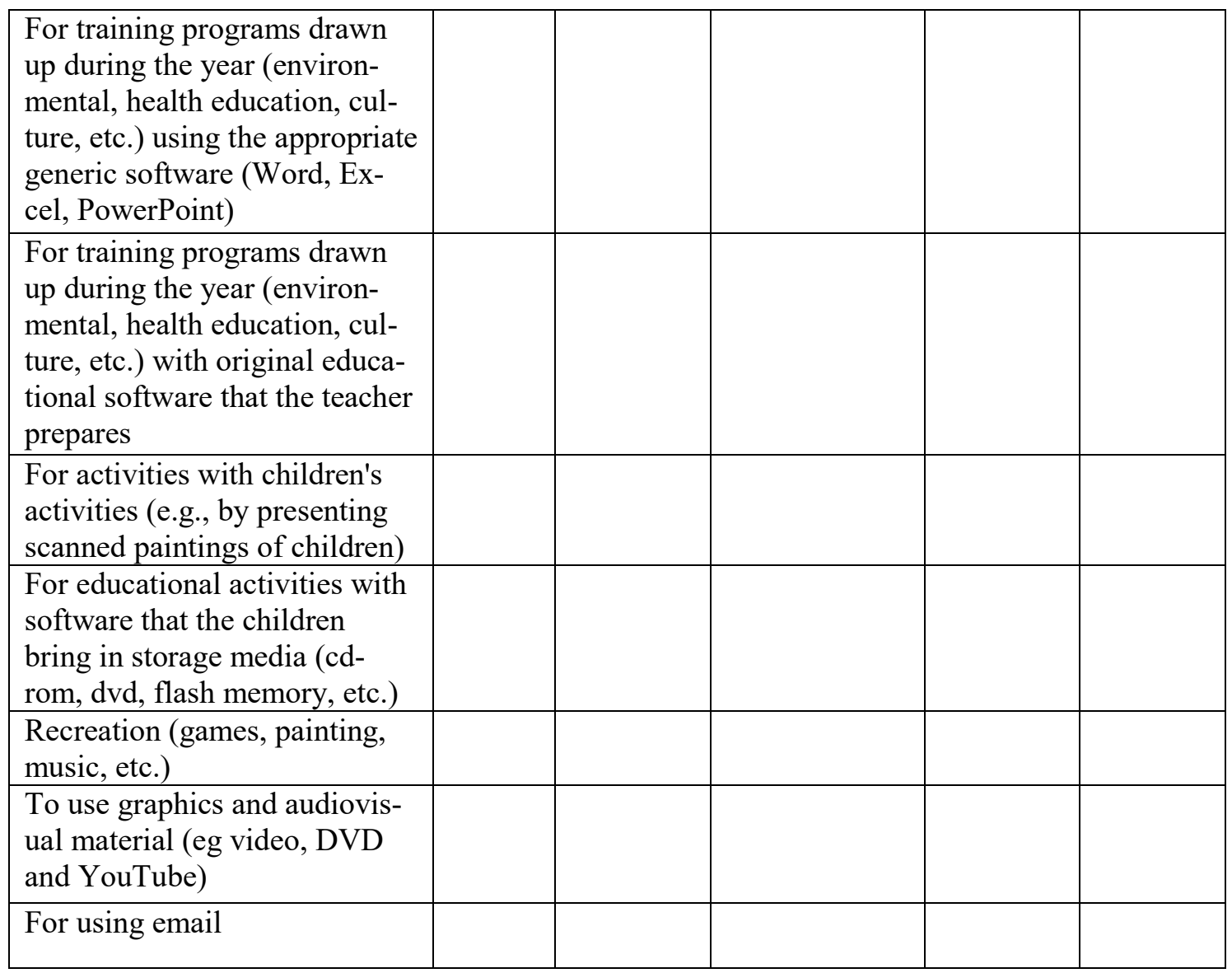

8. For which learning areas of the new curriculum for the kindergarten and how often do you use the computer?

\begin{tabular}{|l|l|l|l|l|l|}
\hline & $\begin{array}{c}\text { Very } \\
\text { Much }\end{array}$ & Usually & Sometimes & Seldom & $\begin{array}{c}\text { No, nev- } \\
\text { er }\end{array}$ \\
\hline For language courses & & & & & \\
\hline For math class & & & & & \\
\hline $\begin{array}{l}\text { For the course of Environ- } \\
\text { mental Education }\end{array}$ & & & & & \\
\hline $\begin{array}{l}\text { For the course of Aesthetic } \\
\text { Education }\end{array}$ & & & & & \\
\hline $\begin{array}{l}\text { For the Health Education } \\
\text { course }\end{array}$ & & & & & \\
\hline
\end{tabular}

9. Would you assess positively the use of ICT in the learning process of kindergartens?

\begin{tabular}{|l|l|l|l|l|}
\hline Very Much & Usually & Sometimes & Seldom & No, never \\
\hline & & & & \\
\hline
\end{tabular}




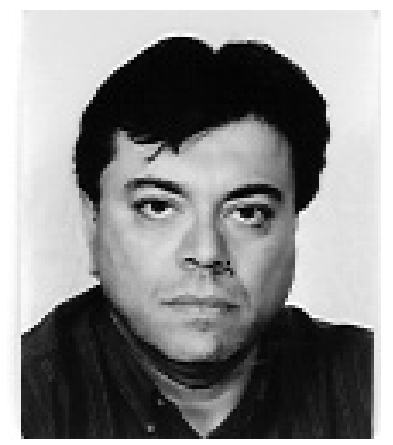

\section{Biographies}

Stefanos K. Goumas was born in Athens, Greece, in 1960. He received the B.Sc. degree in mathematics from the National and Kapodistrian University of Athens, in 1984 and the B.Sc. degree in computer science from the University of Crete, Greece, in 1994. Also he received the M.Sc. and Ph.D. degrees from the Technical University of Crete, Greece, in 1999 and 2008, respectively, all in electronic and computer engineering. After holding a visiting Assistant Professor position with the Technological Educational Institute of Crete, from 1991 to 2003, he joined the Technological Educational Institute of Eastern Macedonian and Trace in 2003 where he is currently an Assistant Professor with the Business Administration Department. Dr. Goumas has been participant investigator in 8 research projects, funded both publicly and privately, in the European Union. He has authored or co-authored over 30 publications in scientific journals and referred conference proceedings. His research interests include automated inspection systems, signal and image processing and analysis, wavelet analysis for data/image processing and compression, neural networks, fuzzy logic and genetic algorithms in pattern recognition applications, multimedia databases, geographical information systems and educational technology. Dr. Goumas is a member of the Greek Computer Society.

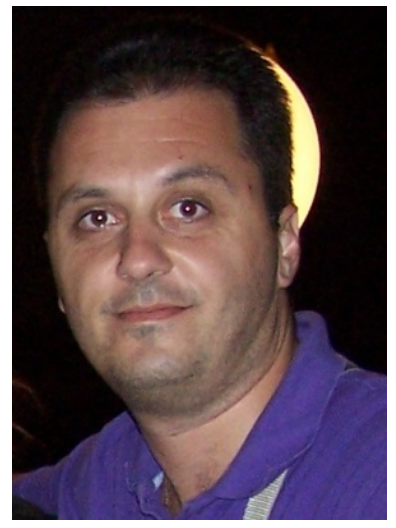

Symeon A. Symeonidis was born in Kavala, Greece, in 1976. He received the B.Sc. degree in Automation engineering from the Technological Educational Institute of Piraeus, Greece, in 2000. Also, he received the M.Sc. Work Based Learning Studies Information Technology degree from Middlesex University, UK, in 2007 and M.Ed. Adult Education degree from Hellenic Open University, Greece, in 2014. He worked as a visiting Lecturer position in Technological Educational Institute of Eastern Macedonian and Trace, from 2002 to 2014. Now, he works as IT teacher in Secondary Education of Kavala. He has authored or co-authored over 10 publications in scientific journals and referred conference proceedings. His research interests include automatic control systems, signal and image processing and analysis, neural networks, fuzzy logic, Databases, multimedia databases, programming, educational technology and Adult education.

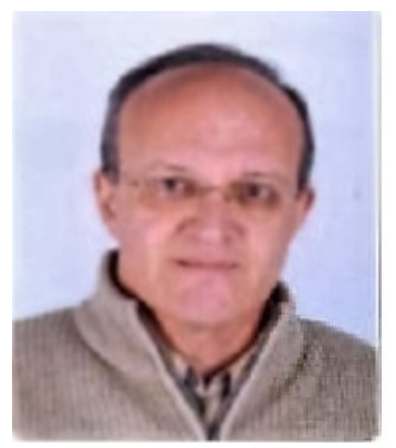

Michael D. Salonidis was born in Drama, Greece, in 1968. He received the B.Sc. degree at the Pedagogical Academy of Larissa in 1989. In 1999 he graduated from the Pedagogical Department of Alexandrou-polis. He received the M.Sc. from Technological Educational Institute of Eastern Macedonian and Trace in 2015, in Management Science and Information Systems. Since 1996 he is teaching at primary schools. He has authored or co-authored 5 publications in scientific journals and referred conference proceedings. His research interests include Educational Multimedia, Educational Technology, Educational Robotics and E-Learning Services. 